\title{
FIELD HOCKEY IN KINDERGARTENS - OPPORTUNITY, PROSPECT AND CHALLENGE
}

\author{
Antonio Antonov \\ National Sports Academy „Vassil Levski”, Sofia, Bulgaria
}

\begin{abstract}
Introduction Children's health, upbringing and education are questions of present interest of public life in Bulgaria. Early childhood sport has positive contribution to physical development and capacity, but its implementation requires the availability of sport pedagogues, appropriate conditions, equipment, and last but not least, attitude and level of culture of the parents. Methodology Within two consecutive school years (2013/2014 and 2014/2015), Hockey club NSA" has developed, applied and implemented two projects on the program in the period from 18th of November 2013 to 31 st of May 2014 (first project) and from 13th of October 2014 to 29th of May 2015 (second project). The main objective of our research is to reveal the opportunities (i.e., potential and resources), the prospects (i.e. the expected results and benefits) and the challenges (i.e. the difficulties, the threads and the ways to overcome it) in the realization of the additional pedagogical service under the MYS Program and the Club agreement. Results: Through the implementation of the Program and the Contract, more than 170 children are given the opportunity to develop their motor skills and motivation for independent motor activity through active sport activities aimed at improving their health, physical and mental capacity. The project also forms pedagogical skill, habits and motivation for independent work among 40 students from NSA - field hockey specialists.

Discussions: During the implementation of the projects, we focused on the main aspects of the children's biological development, with discussions about - Physical development of the children, Emotional development of the children, Psychological development of children, methodical and organizational tasks, etc. In conclusion, we would like to summarize that the projects under the Program and the Contract, using various forms and means of sport, provide the necessary health status, motor experience, form right attitude towards sport, improve organizational skills and motivation for individual sport activities of the children in the kindergarten age group.
\end{abstract}

Key words: field hockey, kindergarten, project, program, internship practice.

\section{INTRODUCTION}

Children's health, upbringing and education are questions of present interest of public life in Bulgaria. The motor ability plays a major role in physical development, health, balance psyche and children's cheerfulness, which is a priority task of the National Strategy for Development of Physical Education and Sport in the Republic of Bulgaria 2012-2022 / Aleksiev, R., 2005, Aleksiev, R., 2006, Antonov, A., 2015, Banova, V., 2000, Buiuklieva, P., 1992, Gavrilov, V., 2001/. Physical education and sport enable children to self-improve, self-express and self-assertion. Early childhood sport has positive contribution to physical development and capacity, but its implementation requires the availability of sport pedagogues, appropriate conditions, equipment, and last but not least, attitude and level of culture of the parents. Parents stimulating children to actively engage in early-school sport activities create pre- requisites for good education, motivation, activity, love and positive attitude to motor activity.

The program "Sport for Children in Kindergartens" (in the test as "Program") was developed in accordance with one of the main priorities of the Ministry of Youth and Sports (MYS) - implementation, development and optimization of the motor regime of the children in kindergartens, in compliance with the current legislation in this area / Obrazetch 12, KH NSA, 2013 Programa "Sport za dezata v detskite gradini", MFVS, 2013, Programa "Sport za dezata v detskite gradini”, MMS, 2014 /.

The program defines the terms and conditions for children's participation in kindergartens in free exercise classes and various entertaining games, and creates opportunities through the forms and means of physical culture and sport for acquiring 
knowledge, skills and habits for systematic activities of a particular kind of sport.

Since the program's approval in 2012, it has gained increasing popularity for MYS project funding by hundreds of sport organizations and has enabled thousands of children from 3 to 6 years of age to practice both traditional and new - not so popular individual and collective games that are popular in Bulgaria but suitable for pre-school age.

Law changes since 1989 have enable NGOs in the field of sport, music, culture and education to com-

\section{METHODOLOGY}

Within two consecutive school years (2013/2014 and 2014/2015), the non-profit organization "Hockey club NSA" (The club) has developed, applied and implemented two projects on the program in the period from $18^{\text {th }}$ of November 2013 to $31^{\text {st }}$ of May 2014 (first project) and from $13^{\text {th }}$ of October 2014 to $29^{\text {th }}$ of May 2015 (second project). The development and implementation of the projects, united effort and ambition of the club, together with the MYS and the partnership of $79^{\text {th }}$ Municipality Kindergarten "Slunchtze", to develop and popularize field hockey among children in kindergartens. In the realization of the project, we found two useful practices (directions): $1^{\text {st }}$ direction - the children had the opportunity to experience new, unconventional and attractive sport, practicing it for health and enrichment of their motor skills and abilities, and $2^{\text {nd }}$ - dozens of students have had the opportunity in real conditions to acquire valuable pedagogical experience and skills working with children.

The implemented projects, the established useful practices of the Program, but above all the interest among children, parents and the governing body of 79th Municipality Kindergarten "Slunchtze" revealed the possibility of providing additional paid pedagogical service (contract). In this connection, on 12th of June 2015, on the grounds of Art. 19, para. 3, Art. 44, para. 1 of the Rules and regulation for implementation of the National Education law was signed a contract between the kindergarten and the Club, with the object of awarding an additional pedagogical service for training the children in kindergarten discipline field hockey - for the period 01.10.2015-31.05.2016. /Dogovor, 2015/ plement and diversify the curriculum of kindergartens through additional pedagogical services consistent with their aims and activities. In the form of extra-curricular activities in sports, music, dancing, studying foreign languages, etc., on one hand, pre-school children can touch the magic of sport, music, art, etc., on the other hand, to NGOs to realize their goals by promoting their activities, pre-sport selection and enrichment of pedagogical skills of coaches working with pre-school children (4-6 years).

The main objective of our research is to reveal the opportunities (i.e., potential and resources), the prospects (i.e. the expected results and benefits) and the challenges (i.e. the difficulties, the threads and the ways to overcome it) in the realization of the additional pedagogical service under the MYS Program and the Club agreement.

\section{RESULTS}

Through the implementation of the Program and the Contract, children are given the opportunity to develop their motor skills and motivation for independent motor activity through active sport activities aimed at improving their health, physical and mental capacity.

The project also form pedagogical skill, habits and motivation for independent work among students from NSA - field hockey specialists, who apply in practice their methodical $\left(3^{\text {rd }}\right.$ and $4^{\text {th }}$ year of their study) and coaching practice (4 $4^{\text {th }}$ year of their study) as an additional pedagogical service in the kindergarten.

\section{Target group and pedagogical resource}

During the preparation and implementation of the projects under the Program (2013/2014 and 2014/2015) and the Contract (2015/2016), specific targeting was the selection of children and their dividing by groups according to the parameters se in the Project (see Table 1). The target group was 4-6-year-old, and in 2016 - mostly 6-year-old children from the pre-school groups who had undergone one or two years of training under the Program. 
Table 1. Planned project indexes for 2014 and 2015 (7).

\begin{tabular}{|c|c|c|c|c|c|c|c|c|}
\hline $\begin{array}{l}\grave{J} \\
\stackrel{\partial}{J}\end{array}$ & 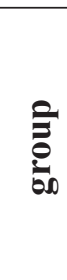 & 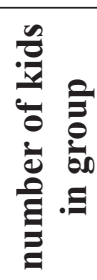 & 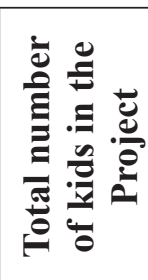 & 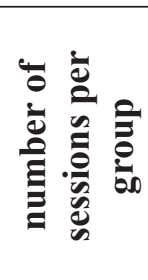 & 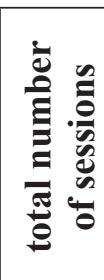 & 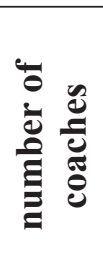 & 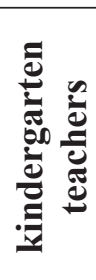 & 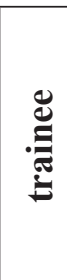 \\
\hline $2013 / 14$ & 4 & 20 & 80 & 56 & 224 & 2 & 8 & 12 \\
\hline $2014 / 15$ & 4 & 15 & 60 & 56 & 224 & 2 & 8 & 12 \\
\hline $2015 / 16$ & 2 & 12 & 24 & 56 & 112 & 2 & 4 & 10 \\
\hline
\end{tabular}

Note: In blue - Program project indexes, in yellow - indexes of the project under the Contract.

Table 2. Reported Project indexes in 2014 and 2015 /7/.

\begin{tabular}{|c|c|c|c|c|c|c|c|c|c|c|}
\hline 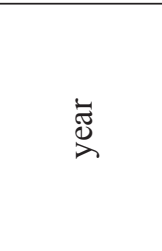 & 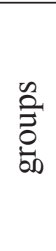 & 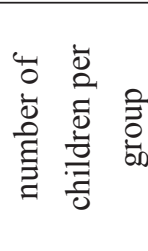 & 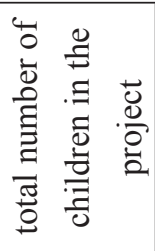 & 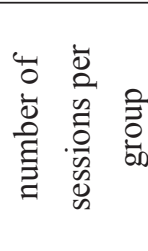 & 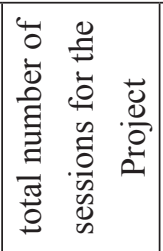 & 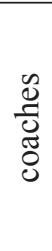 & 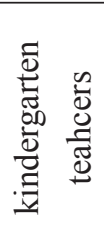 & 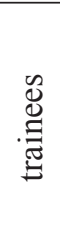 & 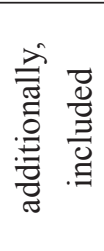 & 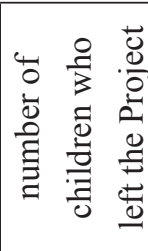 \\
\hline $2013 / 14$ & 4 & $20-25$ & 88 & 51 & 153 & 1 & 8 & 16 & 10 & 15 \\
\hline $2014 / 15$ & 4 & $15-20$ & 68 & 56 & 224 & 2 & 8 & 14 & 10 & 15 \\
\hline $2015 / 16$ & 1 & 12 & 20 & 62 & 70 & 1 & 4 & 10 & 10 & 10 \\
\hline
\end{tabular}

Note: In blue - Program project indexes, in yellow - indexes of the project under the Contract.

\section{DISCUSSION}

The pedagogical resource of the two coaches working with a group of 20 children provided by the projects (2014 and 2015) under the Program were extremely insufficient to secure the safety of the training session. The experience of leading schools and world practices in field hockey clearly demonstrate, that when working with pre-school children, the maxim number of participants per training session is 12 working with two coaches. During the implementation of the project under the Contract (2016) the above-mentioned circumstance was preplanned. It should be noted that the ratio of 12 children and 2 coaches require some training area requirements - minimum 10 sq. $\mathrm{m}$ per children. The age, skills level with stick and ball and the safety measures require partial individual work with children and the use of additional pedagogical resources - field hockey students who taking part in the project cover their auditorium on different subjects - teaching, methodical and internship practices. The total number of trainees involved in the project was 40 students: 16 in 2014, 14 in 2015 and 10 in 2016 (see Table 2).

Expected results

During the implementation of the projects, we fo- cused on the main aspects of the children's biological development (Aleksiev, 2005, 2006; Antonov, 2015; Damjanova, Yordanova, Simeonova, 2008; Stamatov, 2000, 2012; Todorov, Gutev, Dobrev, 2016)

Physical development of the children. Practicing different types of sports, incl. field hockey improves children overall functional condition, strengthens the locomotor system, improves flexibility, develop strength and speed, has a positive effect on coordination and spatial orientation. Children who are physically active have less weight problems. Sport has a long-term positive influence on motor habits, as well as proper attitude towards one's own body health (Antonov, 2015; Banova, 2000; Buiuklieva,1992; Gavrilov, 2001; Damianova, Iordanova, Simeonova, 2008).

Emotional development of the children. Different types of sport games, incl. field hockey also contribute to the positive emotional development of children. During the game, they experience emotions they would not experience in other activity as standing in front of TV or computer. Emotions can be positive or negative, but more important is acquiring skills to control them. In eventual loss in 
sport event, the child is disappointed and sad, but with the proper help of the sport pedagogue, this emotion is mastered and in result we have emotional growth. The positive emotion of victory literally gives wings to children, making them feel confident and happy /Stamatov, R., 2000/.

\section{Psychological development of children}

Human psychic is of great importance for his life. From this point of view, the psychological development of a child is of particular importance. Through sport, children strengthen and improve their psyche, overcoming various difficulties, both physically, psychologically and emotionally. The feeling of victory over itself contributes to the self-esteem, satisfaction, good self-confidence of the child and the building of his/her individuality (Stamatov, 2012)

\section{Social development of children}

Through collective games, incl. field hockey children communicate in a specific way that has positive contribution to their social development. They learn leadership, teamwork, mutual help, compliance, and so on.

\section{Moral development of children}

First of all, through the sport, children learn how to stand out winning and losing, which is of immense importance for their behavior at all. Another important feature is the so-called in sports fair play, honest, correct attitude towards opponents and teammates.

\section{CONCLUSION}

The realization of project in $79^{\text {th }}$ Municipality Kindergarten "Slunchtze" under the Ministry of Youth and Sports" Program for the period 2013-2014 and 2014-2015 and under the Contract for additional pedagogical service for educating children in field hockey for the period 2015-2016 gave us the basis to draw the following conclusions and recommendations:

1. In total 156 children aged 4 to 6 years were part of the Project for 2014 and 2015 - an average of 78 children divided into four groups of 20 children per group. In the project under the Contract participated 12 children and only one group was formed.

2. A total of 337 activities were performed in the 2014 and 2015 projects ( $84 \%$ of the 448 planned for the two years). The number of activities in the project under the Contract in 2016 were 70, i.e. $11 \%$ above the planned 62 .

3. Three coaches and 30 trainees took part in the activities of the projects under the Program for the period 2014 and 2015, and under the Contract -1 coach and 10 trainees, i.e. each coach gave his/her pedagogical skills to 10 student trainees. The workload if coaches and trainees working on the program in 2014 and 2015 is several times higher than that of the contract in 2016 comparing the number if group and the range of children.

4. The projects under the Program and the Contract created a prerequisite for realization of the indexes planned by the coaches as follows - 87\% (under the Program) and 111\% (under the Contract). The projects are excellent opportunity for young pedagogues to gain practical experience and valuable knowledge and skill to work with pre-school children. Particularly important for young educators and coaches is the ability to apply safety measures when working with pre-school children.

5. The children who took part in the projects under the Program in 2013-2015 have acquired initial skills and knowledge for practicing field hockey. The positive emotions and pleasant moments most likely cause $29 \%$ of the participating children in the projects under the Program optionally to try again playing field hockey under the Contract for paid additional pedagogical service for education in field hockey.

6. The analysis of the results from the projects under the Program and the Contracts gives us valuable methodological and scientific-applied information regarding the effectiveness of field hockey in pre-school period.

On the other hand, the difficulties and problems related to the realization of the projects gave us reason to make recommendations to lawmakers and coaches practice:

- In collective sports, such as field hockey, number of participants in pre-school age period should not exceed 12. The greater number of children involved in training process requires higher vigilance and control and is a serious prerequisite for risky situation, injuries, and are difficult to organized and have lower training 
process efficiency.

- For pre-school children, hockey activities should be conducted in a positive emotional environment with appropriate to the age implements (sticks and balls, etc.).

- The lack of practical experience and specialized literature - methodical guides and literature for working with children aged 4-6 years in field hockey, hinders both the development of programs by the staff of MYS and the work of sport specialists (coaches, sport pedagogues, trainees, mentors) and often leads to the planning of unsuitable for the age training sessions.

In conclusion, we would like to summarize that the projects under the Program and the Contract, using various forms and means of sport, provide the necessary health status, motor experience, form right attitude towards sport, improve organizational skills and motivation for individual sport activities of the children in the kindergarten age group.

\section{REFERENCES}

Aleksiev, R. (2005). Dvigatelnata deinost v detskata gradina, Yuni ekspres.

Aleksiev, R. (2006). Dvigatelnata aktivnost na deteto $v$ tdetskata gradina, Yuni ekspres Schumen

Antonov, A. (2015). Proektite po programa Sport za dezata v detskite gradini - dobro nachalo v sporta za dezata i mladite pedagozi, Spezialna nagrada za uchastie vav Vtorata Nauchno - prakticheska konferenzija "Dobrite praktiki v oblastta na zdravoslovnija nachin na jivot, FVS v obrazovatelnite instituzii, sp. Az Buki, Profesionalno obrazovanie. br. 6 "

Banova, V. (2000). Deteto ot 3 do 6 godini. Rakovodstvo za izsledvane na deteto, Sofia

Buiuklieva, P. (1992). Podvijnite igri v detskata gradina,
Medicina i Fizkultura, Sofia

Damjanova, S., Iordanov, N., Simeonova, T. (2008). Zdraveto I fizicheskite kachestva na dezata ot preduchilishtnata vazrast $\mathrm{v}$ zavisimost ot zanimanijata sas sport, Nauchni trudove na Rusenskija Universitet, 2008, tom 47, serija 5.4

Dogovor ot 12 Iuni, 2015 g. mejdu 79 ODZ "Slanchiche" i Klub po hokei NSA, 2015

Gavrilov, V. (2001). Eksperimintalno obosnovavane na rannoto obuchenie po futbol s 5 - 7 godishni deza, Dissertation

Obrazets 12, Formuliar na sadarjatelen otchet za izpalnenie na proekt po programata na MMS “Sport za dezata $\mathrm{V}$ detskite gradini” uc; proekt vh. N 36-00-507/26.11.2013

Programa "Sport za dezata v detskite gradini", utvardena sas zapoved N RD-09-399/27.05.2013, MFVS

Programa "Sport za dezata v detskite gradini", utvardena sas zapoved N RD - 09-254/26.05.2014, MMS.

Stamatov, R. (2000). Emotzionalnoto razvitie na deteto, Plovdivsko Universitetsko Izdanie, Plovdiv

Stamatov, R. (2012). Detska psihologija, Izdatelska kashta "Hermes"

Todorov, G., Gutev, Gr., Dobrev, Jor. (2016). Izsledvane vlijanieto na programata za Detska atletika na IAAF varhu razvitieto na kachestvoto barzina pri podrastvashtite (10-12 godishni), Mejdunarodna Nauchna Konferenziya na Katedra "Leka atletika" 2016, sp. "Leka atlrtika I Nauka”, br. 1 (16), BPS OOD, Sofia, pp 99-104

Corresponding author: Assoc. prof. Antonio Antonov, Phd Football and Tennis department National Sports Academy "Vassil Levski" Studentski grad, 21, Acad. Stefan Mladenov str. Sofia 1700, Bulgaria E-mail: antonio_hockey@yahoo.com 